\title{
CSM-CERES-Rice model to determine management strategies for lowland rice
} production

\author{
Saythong Vilayvong ${ }^{1}$, Poramate Banterng ${ }^{1,2 *}$, Aran Patanothai ${ }^{1}$, Krirk Pannangpetch ${ }^{1}$
}

${ }^{1}$ Khon Kaen University/Faculty of Agriculture - Dept. of Plant Science and Agricultural Resources - Khon Kaen - 40002 - Thailand.

${ }^{2}$ Khon Kaen University/Faculty of Agriculture - Plant Breeding Research Center for Sustainable Agriculture.

*Corresponding author <pbanterng@hotmail.com>

Edited by: Gerrit Hoogenboom

Received November 21, 2013

Accepted December 19, 2014
ABSTRACT: The cropping system model, namely, the crop environment resource synthesis-rice (CSM-CERES-Rice) model, is a decision supporting tool for the design of crop management. This study aimed to determine management practices for increasing rice (Oryza sativa L.) production in Laos by using the CSM-CERES-Rice model. The model was evaluated with data sets from the TDK8 and TDK11 cultivars in farmers' fields in the Vientiane plain in 2012. Anthesis and harvesting dates, growth and yield for various management scenario combinations (eight transplanting dates $x$ two levels of plant densities $x$ three rates of nitrogen (N) fertilizer application) for both cultivars were simulated by the model from 1980 to 2012 . The model evaluation results showed strong agreement between simulated and observed data for days to harvest with a difference within four days. The model provided acceptable accuracy for grain yields with normalized root mean square error values ranging between 1 and $16 \%$. The results from the model application indicated that TDK8 and TDK11 produced similar yields. Transplanting TDK8 with two plant densities produced similar yields. The highest yield for both cultivars was achieved on the transplanting date of 15 Jan. $\mathrm{N}$-fertilizer application at 60 and $120 \mathrm{~kg} \mathrm{~N}^{-1}$ was able to increase yield for TDK8 by 50 and 87 $\%$, respectively, and for TDK11 by 54 and $70 \%$, respectively. Rice transplanted on 15 Jan with 5 seedlings hill-1 and $\mathrm{N}$-fertilizer at $120 \mathrm{~kg} \mathrm{~N}^{-1} \mathrm{had}^{-1}$ he highest average yield for both cultivars with 6,460 and $6,351 \mathrm{~kg} \mathrm{ha}^{-1}$ for TDK8 and TDK11, respectively. The CSM-CERES-Rice model is an alternative tool in determining crop management practices for rice production.

Keywords: crop simulation, N-fertilizer application, planting practice, transplanting date

\section{Introduction}

Rice (Oryza sativa L.) is the most important food for half of the world's population especially in Asia (Schiller et al., 2006). In Laos, rice is mostly cultivated in the plain areas which account for more than $80 \%$ of the agricultural areas of the country. Records from the Office of Agricultural Statistics of Laos indicate that the average rice yield is lower than the expected yield level of $2.5 \mathrm{t} \mathrm{ha}^{-1}$. There are several factors that impact rice production, including management practices such as cultivar use, transplanting date, plant density, fertilizer application, irrigation amongst others. Identification of suitable crop management practices could provide information for designing a plan to increase the rice yield of this production area. However, this process is time consuming and expensive as many years of experimental trials are required. In addition, cropping systems are extremely complex and many factors have to be considered to achieve long-term sustainability (Geng et al., 1990) in major rice growing areas.

The CSM-CERES-Rice model has been developed to support decision making in agronomic research, crop production and land-use planning. It has been included in the decision support system for agrotechnology transfer (DSSAT). The CSM-CERES-Rice model is physiologically based and simulates daily canopy photosynthesis, respiration, growth, biomass partitioning and crop development as a function of input information, including daily weather conditions, soil proper- ties, management practices and cultivar characteristics (Jones et al., 2003).

This model was introduced as a decision-supporting tool and its performance has been assessed for rice-wheat cropping systems to increase land and resource use efficiency (Timsina and Connor, 2001; Sarkar and Kar, 2006; Timsina and Humphreys, 2006). The model has been evaluated in a number of agro-environments and crop management strategies (Cheyglinted et al., 2001; Singh et al., 2007; Vilayvong et al., 2012; Yao et al., 2005). It has also been used to determine better rice management systems under irrigated conditions (Ahmad et al., 2012) and simulate rice yield under certain agronomic management practices and changing climatic scenarios (Lamsal and Amgain, 2010). Therefore, the CSM-CERES-Rice model offers the opportunity of a tool to determine crop management for improving rice productivity.

Currently, the lack of this model assessment has limited the application in investigating the interaction of transplanting dates, plant densities and $\mathrm{N}$-fertilizer application for lowland rice under both irrigated and rainfed conditions in tropical regions such as Laos. This study aimed to determine management practices that will increase rice production in Laos by using the CSMCERES-Rice model.

\section{Materials and Methods}

\section{Model evaluation}

The input data required to evaluate the CSM- 
CERES-Rice model in the DSSAT v4.5 include rice management practices, crop details, soil properties, daily weather conditions and genetic coefficients. Data on rice management, including cultivars used, transplanting date, planting method, plant spacing, fertilization, weed control, irrigation, pest control, harvest time and others production practices were obtained from farmer interviews (nine households) in 2012 in the Xaythani district $\left(18^{\circ} 4^{\prime} \mathrm{N}, 102^{\circ} 36^{\prime} \mathrm{E}\right.$ and $170 \mathrm{~m}$ above mean sea level), Vientiane, Laos. These data cover the range of rice management practices in Vientiane. Therefore, it would constitute information representative of rice production in this area. Crop details include harvest maturity date and dry weight of grain yield for TDK8 and TDK11 cultivars from nine farmers' fields.

The sample plots (three plots for each cultivar) were selected for the collection of data from an area of 4 $\mathrm{m}^{2}$ for each plot. The soil surface and soil profile characteristics for two soil groups in the Vientiane plain were obtained from the Soil Survey and Land Classification Center, National Agriculture and Forestry Research Institute, Ministry of Agriculture and Forestry, Laos (Table 1). The genetic coefficients of TDK8 and TDK11 (Table 2) were obtained from our previous study (Vilayvong et al., 2012), that also indicated that the genetic coefficients of TDK 8 and TDK11 cultivars are sufficiently accurate for further application of CSM-CERES-Rice to support decision making.

The management, soil, climatic and crop data for nine farmers' fields and the genetic coefficients of TDK8 and TDK11were used as input data in the DSSAT v4.5. Model evaluation was performed by comparing the simulated values with their corresponding observed values from nine farmers' fields. The root mean square error $\left(\right.$ RMSE $_{n}$ ) value (Wallach and Goffinet, 1987) was used to test the agreement between simulated and observed data. Low RMSE value indicates strong agreement between the data sets. The RMSE $E_{n}$ value gives a measure (\%) of the relative difference of simulated versus observed data. The simulation is considered excellent if the $\mathrm{RMSE}_{\mathrm{n}}$ value is less than $10 \%$, good if the RMSE ${ }_{n}$ is greater than $10 \%$ and less than $20 \%$ and fair if the RMSE ${ }_{n}$ is greater than 20 $\%$ and less than $30 \%$ (Loague and Green, 1991).

Table 1 - The information for the top soil layer (depth 0-15 and 15-30 $\mathrm{cm})$ for two soil groups in the Vientiane plain, Laos.

\begin{tabular}{lccccc}
\hline \multirow{2}{*}{ Soil characteristic } & \multicolumn{4}{c}{ Soil group } \\
\cline { 2 - 3 } & \multicolumn{2}{c}{ Acrisols } & & \multicolumn{2}{c}{ Alisols } \\
\cline { 2 - 3 } \cline { 5 - 6 } & $0-15 \mathrm{~cm}$ & $15-30 \mathrm{~cm}$ & & $0-15 \mathrm{~cm}$ & $15-30 \mathrm{~cm}$ \\
\hline Soil texture & Loam & Loam & & Sandy loam & Sandy loam \\
Sand (\%) & 52 & 46 & & 54 & 55 \\
Clay (\%) & 18 & 24 & & 15 & 16 \\
Silt (\%) & 30 & 30 & & 31 & 29 \\
pH in $\mathrm{H}_{2} \mathrm{O}$ & 5.1 & 5.1 & & 5.0 & 5.1 \\
Total N (\%) & 0.2 & 0.2 & & 0.1 & 0.1 \\
Organic matter (\%) & 3.2 & 3.2 & & 2.2 & 2.4 \\
Bulk density $\left(\mathrm{g} \mathrm{cm}^{-3}\right)$ & 1.5 & 1.5 & & 1.5 & 1.5 \\
\hline
\end{tabular}

Table 2 - The genetic coefficients of the TDK8 and TDK11 cultivars for the CSM-CERES-Rice model.

\begin{tabular}{lll}
\hline \multirow{2}{*}{ Genetic coefficient } & \multicolumn{2}{c}{ Cultivar } \\
\cline { 2 - 3 } & TDK8 & TDK11 \\
\hline Phenology coefficient & & \\
P1: Growing degree day (GDD) for the basic & 415 & 409 \\
vegetative phase ( ${ }^{\circ} \mathrm{C}$ day) & 195 & 199 \\
P2R: Photoperiod sensitivity coefficient ( ${ }^{\circ} \mathrm{C}$ day) & 520 & 400 \\
P5: GDD from the beginning of grain filling to & 10.6 & 11.2 \\
physiological maturity ( ${ }^{\circ} \mathrm{C}$ day) & & \\
P20: Critical day length (h) & 40 & 42 \\
Growth coefficient & 0.025 & 0.025 \\
G1: Potential spikelet number coefficient & 0.8 & 0.9 \\
G2: Single grain weight (g) & 0.8 & 0.8 \\
G3: Tillering coefficient &
\end{tabular}

Source: Vilayvong et al. (2012)

\section{Simulation for different management scenarios}

The input data required for model simulation include genetic coefficients, soil properties, daily weather conditions and rice management. The genetic coefficients of TDK8 and TDK11 (Table 2) were obtained from Vilayvong et al. (2012). The historical daily weather data for Vientiane from 2001 to 2012 (12 years) include maximum and minimum temperatures, solar radiation and rainfall (Figure 1). These historical weather data were then used as the input data for the WeatherMan program in DSSAT v4.5 to generate the weather parameters for long-term simulation.

Model simulation for different management scenarios was conducted to determine crop management practices for rice production in the Vientiane plain. The scenarios for crop management were first defined by following both local extension recommendations and current farmers' management practices. Growing rice in-season under both rainfed and irrigated conditions were specified for seven transplanting dates in the rainy season, e.g. 15 June, 30 June, 15 July, 30 July, 15 Aug, 30 Aug and 15 Sept. Another growing rice off-season under irrigated conditions was also set as 15 Jan transplanting date (Figure 1).

Irrigation and water management for all planting dates were set as automatic application when required by the crop. The common plant densities of 1 seedling hill $^{-1}$ and 5 seedlings hill ${ }^{-1}$ with $20 \mathrm{~cm} \times 20 \mathrm{~cm}$ of plant spacing were employed. $\mathrm{N}$-fertilizer was applied at the rates of $60 \mathrm{~kg} \mathrm{~N} \mathrm{ha}^{-1}$ (the rate recommended by Linquist and Sengxua (2001) for lowland rice in Laos) and 120 $\mathrm{kg} \mathrm{N} \mathrm{ha}^{-1}$ (two times the recommended rate) with three splits (recommended by Iqbal et al., 2008) of $35 \%$ at 20-25 days after transplanting (DAT), $45 \%$ at 40-45 DAT and $20 \%$ at 60 DAT. The most popular glutinous rice cultivars TDK8 and TDK11 in Vientiane plain were used for simulation scenarios.

The crop management scenario combinations (eight transplanting dates $\times$ two plant densities $\times$ three 


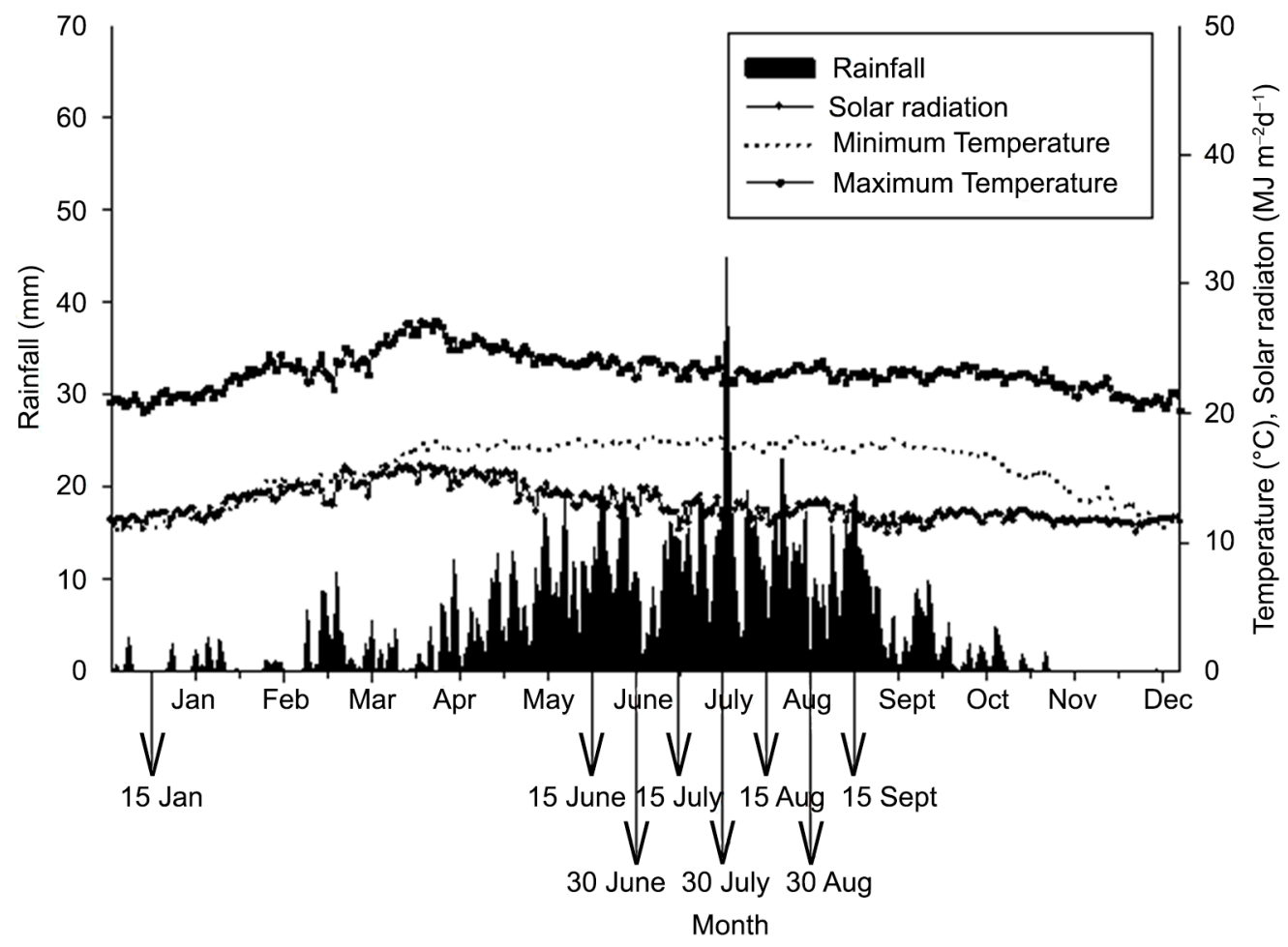

Figure 1 - Average daily maximum temperature, minimum temperature, solar radiation and rainfall over 12 years (2001-2012) for the Vientiane plain, Laos.

rates of $\mathrm{N}$-fertilizer application) were run by the CSMCERES-Rice model for TDK8 and TDK11 cultivars. The simulation was conducted for 33 years from 1980 to 2012. The seasonal analysis program of DSSAT v4.5 was used to evaluate and compare between different combinations of crop management practices.

The simulated data were analyzed statistically using the analysis of variance technique. Treatment means were compared by the least significant difference (LSD) method. All statistical analyses were performed using Statistix 8 software by following Gomez and Gomez (1984). The total production cost and gross income (average simulated yield for $2012 \times$ price of rice) for TDK8 and TDK11 productions under three different rates of $\mathrm{N}$-fertilizer application were also evaluated and they were then used to calculate the net income. The relative values (\%) for total production cost, grain yield and net income were calculated by using the value of each $\mathrm{N}$-fertilizer application rate multiplied by 100 and then divided by the corresponding value for no $\mathrm{N}$-fertilizer application.

\section{Results}

\section{Model evaluation}

Differences between the simulated data and observed data for days to harvest ranged from +2 to -4 days (Table 3 ). The greatest difference (-4 days) was found for TDK8 grown on 13 June 2013 with $\mathrm{N}$-fertilizer at a rate of $80 \mathrm{~kg} \mathrm{~N} \mathrm{ha}^{-1}$ followed by -3 days for TDK11 grown on 10 July 2011 with $\mathrm{N}$-fertilizer at a rate of 73 $\mathrm{kg} \mathrm{N} \mathrm{ha}{ }^{-1}$. Most differences between the simulated data and observed data for grain yield were low, ranging from 31 to $154 \mathrm{~kg} \mathrm{ha}^{-1}$ for RMSE values and 1 to $6 \%$ for RM$\mathrm{SE}$ values (Table 4). However, the highest RMSE value of $556 \mathrm{~kg} \mathrm{ha}^{-1}$ and RMSE value of $16 \%$ were found for TDK8 transplanted on 7 July 2012 with $\mathrm{N}$-fertilizer at a rate of $42 \mathrm{~kg} \mathrm{~N} \mathrm{ha}^{-1}$.

\section{Simulation for management scenarios}

The simulated results for 33 years (from 1980 to 2012) indicated that there were differences $(p<0.05)$ between TDK8 and TDK11 for days to anthesis, days to harvest, biomass and harvest index, whereas there was no difference $(p>0.05)$ between TDK8 and TDK11 in terms of grain yield (Table 5). The results for simulated data showed that TDK8 flowered at 83 DAT and had 122 days to harvest, whereas TDK11 bloomed at 76 DAT and could be harvested at 108 days. TDK 8 was also higher than TDK11 in biomass production $(13,712$ and $12,354 \mathrm{~kg} \mathrm{ha}^{-1}$ for TDK8 and TDK11, respectively), but it was lower than TDK11 as regards harvest index (0.31 and 0.34 for TDK8 and TDK11, respectively). However, these cultivars had no differences in grain yield 44,165 and 4,209 $\mathrm{kg} \mathrm{ha}^{-1}$ for TDK8 and TDK11, respectively). 
Table 3 - Simulated (S) and observed (0) values for days to harvest of TDK8 and TDK11 cultivars grown under different transplanting dates and $\mathrm{N}$-fertilizer application rates in 2012 in Vientiane plain, Laos.

\begin{tabular}{|c|c|c|c|c|c|c|}
\hline \multirow{2}{*}{ Cultivar } & \multirow{2}{*}{ Transplanting date } & \multirow{2}{*}{ No. of seedling hill-1 } & \multirow{2}{*}{$\mathrm{N}$-fertilizer } & \multicolumn{3}{|c|}{ Days to harvest (DATa) } \\
\hline & & & & $S$ & 0 & $S-0$ \\
\hline & & & kg N ha-1 & & & \\
\hline \multirow[t]{6}{*}{ TDK8 } & 13 June 2012 & 1 & 80 & 112 & 116 & -4 \\
\hline & 23 June 2012 & 5 & 129 & 115 & 114 & +1 \\
\hline & 1 July 2012 & 5 & 112 & 118 & 117 & +1 \\
\hline & 3 July 2012 & 5 & 80 & 115 & 115 & 0 \\
\hline & 5 July 2012 & 5 & 73 & 113 & 115 & -2 \\
\hline & 7 July 2012 & 5 & 42 & 114 & 113 & -1 \\
\hline \multirow[t]{3}{*}{ TDK11 } & 8 July 2012 & 5 & 117 & 103 & 103 & 0 \\
\hline & 10 July 2012 & 5 & 73 & 98 & 101 & -3 \\
\hline & 15 July 2012 & 5 & 112 & 102 & 102 & 0 \\
\hline
\end{tabular}

aDAT is days after transplanting.

Table 4 - Simulated (S) and observed (0) values, root mean square error (RMSE) and normalized RMSE (RMSE) for grain yield of TDK8 and TDK11 cultivars grown under different transplanting dates and N-fertilizer application rates in 2012 in Vientiane plain, Laos.

\begin{tabular}{|c|c|c|c|c|c|c|c|}
\hline \multirow{2}{*}{ Cultivar } & \multirow{2}{*}{ Transplanting date } & \multirow{2}{*}{ No. of seedling hill ${ }^{-1}$} & \multirow{2}{*}{$\mathrm{N}$-fertilizer } & \multicolumn{4}{|c|}{ Grain yield } \\
\hline & & & & $S$ & 0 & RMSE & RMSE $_{n}$ \\
\hline & & & $\mathrm{kg} \mathrm{N} \mathrm{ha}^{-1}$ & - & $\mathrm{kg} \mathrm{ha}^{-1}$ & 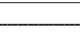 & $\%$ \\
\hline \multirow[t]{6}{*}{ TDK8 } & 13 June 2012 & 1 & 80 & 4,023 & 3,825 & 114 & 3 \\
\hline & 23 June 2012 & 5 & 129 & 5,190 & 5,100 & 52 & 1 \\
\hline & 1 July 2012 & 5 & 112 & 4,633 & 4,888 & 147 & 3 \\
\hline & 3 July 2012 & 5 & 80 & 3,922 & 3,975 & 31 & 1 \\
\hline & 5 July 2012 & 5 & 73 & 3,352 & 3,613 & 150 & 4 \\
\hline & 7 July 2012 & 5 & 42 & 2,437 & 3,400 & 556 & 16 \\
\hline \multirow[t]{3}{*}{ TDK11 } & 8 July 2012 & 5 & 117 & 4,337 & 4,250 & 50 & 1 \\
\hline & 10 July 2012 & 5 & 73 & 3,029 & 2,763 & 154 & 6 \\
\hline & 15 July 2012 & 5 & 112 & 4,121 & 4,038 & 48 & 1 \\
\hline
\end{tabular}

Table 5 - Simulated days to anthesis, days to harvest, biomass and grain yield of TDK8 and TDK11 for two plant densities, three rates of $\mathrm{N}$-fertilizer application and eight transplanting dates for 33 years (from 1980 to 2012) in the Vientiane plain, Laos.

\begin{tabular}{|c|c|c|c|c|c|c|c|c|c|c|}
\hline \multirow[t]{2}{*}{ Management } & \multicolumn{2}{|c|}{$\begin{array}{l}\text { Days to anthesisa } \\
\left.\text { (DAT }{ }^{\mathrm{b}}\right)\end{array}$} & \multicolumn{2}{|c|}{ Days to harvesta ${ }^{\mathrm{a}}\left(\mathrm{DAT} \mathrm{T}^{\mathrm{b}}\right)$} & \multicolumn{2}{|c|}{$\begin{array}{c}\text { Biomassa } \\
\left(\mathrm{kg} \mathrm{ha}^{-1}\right)\end{array}$} & \multicolumn{2}{|c|}{$\begin{array}{l}\text { Grain yielda } \\
\left(\mathrm{kg} \mathrm{ha}^{-1}\right)\end{array}$} & \multicolumn{2}{|c|}{ Harvest index ${ }^{a}$} \\
\hline & TDK8 & TDK11 & TDK8 & TDK11 & TDK8 & TDK11 & TDK8 & TDK11 & TDK8 & TDK11 \\
\hline \multicolumn{11}{|l|}{ Plant density } \\
\hline 1 Seedling hill-1 & $83 \mathrm{~A}$ & $76 \mathrm{~A}$ & $124 \mathrm{~A}$ & $110 \mathrm{~A}$ & $13,518 \mathrm{~B}$ & 11,996 B & $4,154 \mathrm{~A}$ & $4,232 \mathrm{~A}$ & $0.3128 \mathrm{~A}$ & $0.3553 \mathrm{~A}$ \\
\hline 5 Seedlings hill ${ }^{-1}$ & $82 \mathrm{~B}$ & $75 \mathrm{~B}$ & $121 \mathrm{~B}$ & $106 \mathrm{~B}$ & $13,905 \mathrm{~A}$ & $12,712 \mathrm{~A}$ & $4,177 \mathrm{~A}$ & $4,186 \mathrm{~B}$ & $0.3074 \mathrm{~B}$ & $0.3326 \mathrm{~B}$ \\
\hline $\mathrm{LSD}_{0.05}$ & 0.18 & 0.17 & 0.24 & 0.22 & 60.09 & 55.60 & 29.81 & 24.00 & 0.002 & 0.001 \\
\hline \multicolumn{11}{|l|}{$\mathrm{N}$ rate $\left(\mathrm{kg} \mathrm{N} \mathrm{ha}^{-1}\right)$} \\
\hline 0 & $82 \mathrm{~B}$ & $75 B$ & $120 \mathrm{C}$ & $106 \mathrm{C}$ & $9,097 \mathrm{C}$ & $8,669 \mathrm{C}$ & $2,850 \mathrm{C}$ & $2,954 \mathrm{C}$ & $0.3207 \mathrm{~A}$ & $0.3460 \mathrm{~A}$ \\
\hline 60 & $83 \mathrm{~A}$ & $76 \mathrm{~A}$ & $122 \mathrm{~B}$ & $108 \mathrm{~B}$ & $14,472 B$ & $13,270 \mathrm{~B}$ & $4,405 B$ & $4,556 \mathrm{~B}$ & $0.3077 \mathrm{~B}$ & $0.3456 \mathrm{~A}$ \\
\hline 120 & $83 \mathrm{~A}$ & $76 \mathrm{~A}$ & $124 \mathrm{~A}$ & $109 \mathrm{~A}$ & $17,566 \mathrm{~A}$ & $15,123 \mathrm{~A}$ & $5,241 \mathrm{~A}$ & $5,117 \mathrm{~A}$ & $0.3018 \mathrm{C}$ & $0.3404 \mathrm{~B}$ \\
\hline $\mathrm{LSD}_{0.05}$ & 0.22 & 0.21 & 0.30 & 0.27 & 73.60 & 68.09 & 36.51 & 29.39 & 0.002 & 0.002 \\
\hline \multicolumn{11}{|l|}{ Transplanting date } \\
\hline 15 Jan & $82 \mathrm{D}$ & $74 \mathrm{D}$ & $114 \mathrm{~F}$ & $101 \mathrm{~F}$ & $14,811 \mathrm{C}$ & $13,953 \mathrm{~B}$ & $4,889 \mathrm{~A}$ & $4,766 \mathrm{~A}$ & $0.3320 \mathrm{~B}$ & $0.3414 \mathrm{D}$ \\
\hline 15 June & $85 \mathrm{~A}$ & $78 \mathrm{~A}$ & $120 \mathrm{E}$ & $108 \mathrm{C}$ & $11,096 \mathrm{H}$ & $10,383 \mathrm{H}$ & $3,760 \mathrm{G}$ & $3,840 \mathrm{~F}$ & $0.3446 \mathrm{~A}$ & $0.3726 \mathrm{~A}$ \\
\hline 30 June & $84 \mathrm{~B}$ & $78 \mathrm{~A}$ & $121 \mathrm{D}$ & $108 \mathrm{C}$ & $11,552 \mathrm{G}$ & $10,610 \mathrm{G}$ & $3,769 \mathrm{G}$ & $3,823 \mathrm{~F}$ & $0.3315 \mathrm{~B}$ & $0.3637 \mathrm{~B}$ \\
\hline 15 July & $83 \mathrm{C}$ & $77 \mathrm{~B}$ & $120 \mathrm{E}$ & $107 \mathrm{D}$ & $12,331 \mathrm{~F}$ & $11,203 \mathrm{~F}$ & $3,893 \mathrm{~F}$ & $3,861 \mathrm{~F}$ & $0.3192 \mathrm{C}$ & $0.3472 \mathrm{C}$ \\
\hline 30 July & $82 \mathrm{D}$ & $75 C$ & $120 \mathrm{E}$ & $106 \mathrm{E}$ & $13,036 \mathrm{E}$ & $11,597 \mathrm{E}$ & $4,080 \mathrm{D}$ & $3,940 \mathrm{E}$ & $0.3152 \mathrm{D}$ & $0.3406 \mathrm{D}$ \\
\hline 15 Aug & $82 \mathrm{D}$ & $75 C$ & $123 \mathrm{C}$ & $107 \mathrm{D}$ & $14,131 \mathrm{D}$ & $12,304 \mathrm{D}$ & $4,341 \mathrm{C}$ & $4,247 \mathrm{D}$ & $0.3081 \mathrm{E}$ & $0.3449 \mathrm{C}$ \\
\hline 30 Aug & $82 \mathrm{D}$ & $75 C$ & $128 \mathrm{~B}$ & $111 \mathrm{~B}$ & 15,669 B & $13,589 \mathrm{C}$ & $4,601 \mathrm{~B}$ & $4,571 \mathrm{C}$ & $0.2943 \mathrm{~F}$ & $0.3366 \mathrm{E}$ \\
\hline 15 Sept & $82 \mathrm{D}$ & $74 \mathrm{D}$ & $130 \mathrm{~A}$ & $114 \mathrm{~A}$ & $17,066 \mathrm{~A}$ & $15,192 \mathrm{~A}$ & $3,990 \mathrm{E}$ & $4,624 \mathrm{~B}$ & $0.2359 \mathrm{G}$ & $0.3047 \mathrm{~F}$ \\
\hline $\mathrm{LSD}_{0.05}$ & 0.37 & 0.34 & 0.49 & 0.45 & 120.18 & 111.20 & 59.62 & 47.99 & 0.003 & 0.003 \\
\hline Average $^{a}$ & $83 a$ & $76 b$ & $122 \mathrm{a}$ & $108 \mathrm{~b}$ & $13,712 \mathrm{a}$ & $12,354 \mathrm{~b}$ & $4,165 \mathrm{a}$ & $4,209 a$ & $0.3101 b$ & $0.3440 \mathrm{a}$ \\
\hline $\mathrm{LSD}_{0.05}$ for average & \multicolumn{2}{|c|}{0.15} & \multicolumn{2}{|c|}{0.29} & \multicolumn{2}{|c|}{187.12} & \multicolumn{2}{|c|}{55.58} & \multicolumn{2}{|c|}{0.002} \\
\hline
\end{tabular}

aValues in the column (capital letters) and row (small letters) followed by the same letter are not different $(p<0.05)$. bDAT is days after transplanting. 
Differences in plant population densities affected $(p<0.05)$ days to anthesis, days to harvest, biomass and harvest index for both cultivars, but it did not affect $(p>0.05)$ grain yield of TDK8 (Table 5). Biomass of TDK 8 and TDK11 grown at 5 seedlings hill ${ }^{-1}$ was higher than that grown at 1 seedling hill ${ }^{-1}$, but both TDK8 and TDK11 grown at 1 seedling hill-1 had a higher harvest index than those grown at 5 seedlings hill-1.

$\mathrm{N}$-fertilizer rates also affected $(p<0.05)$ days to anthesis, days to harvest, biomass, grain yield and harvest index for both rice cultivars (Table 5). For both cultivars with higher $\mathrm{N}$-fertilizer application, days to anthesis and days to harvest were slightly delayed, whereas biomass and grain yield were increased. However, N-fertilizer reduced the harvest index in both cultivars.

Transplanting date affected $(p<0.05)$ days to anthesis, days to harvest, biomass, grain yield and harvest index (Table 5). The longest days to anthesis was recorded for the crop transplanted on 15 June in TDK8 (85 DAT) and 15 June and 30 June in TDK11 (78 DAT). Whereas the longest days to harvest was recorded for the crop transplanted on 15 Sept for both cultivars with 130 and 114 DAT for TDK8 and TDK11, respectively. The shortest periods of life cycle were recorded for both cultivars transplanted on 15 Jan.

The crop transplanted on 15 Sept produced the highest above ground biomass with $17,066 \mathrm{~kg} \mathrm{ha}^{-1}$ for TDK8 and 15,192 $\mathrm{kg} \mathrm{ha}^{-1}$ for TDK11. The crop grown on other transplanting dates during the period 15 June to 15 Aug had low biomass. The crop transplanted on 15 Jan produced the highest grain yield with 4,889 and 4,766 $\mathrm{kg} \mathrm{ha}^{-1}$ for TDK8 and TDK11, respectively. TDK8 and TDK11 transplanted on 15 June had the highest harvest index. Both cultivars had the lowest harvest index when they were planted on 15 Sept.

According to simulated results for all management combinations, a delay in transplanting dates and an increase in the rate of $\mathrm{N}$-fertilizer application could increase grain yields for all cultivars and plant densities, except for a combination of the crop transplanted on 15 Jan with 1 seedling hill-1 and $120 \mathrm{~kg} \mathrm{~N}^{-1}$ (Figure 2). A plant density of 5 seedlings hill ${ }^{-1}$ along with $120 \mathrm{~kg} \mathrm{~N}$ $\mathrm{ha}^{-1}$ and a transplanting date of 15 Jan had the highest average grain yield for both TDK8 $\left(6,460 \pm 403 \mathrm{~kg} \mathrm{ha}^{-1}\right)$ and TDK11 $\left(6,351 \pm 410 \mathrm{~kg} \mathrm{ha}^{-1}\right)$ when compared to the other management combinations. In addition, the range of the simulated rice grain yield around the median for this management combination was also small, especially in TDK8.

\section{Contribution of $\mathrm{N}$-fertilizer application to produc- tion cost, grain yield and income}

Economic assessment for rice production under three rates of $\mathrm{N}$-fertilizer application was also made by using the simulated results from 2012. The results indicated that $\mathrm{N}$-fertilizer rates of 60 and $120 \mathrm{~kg} \mathrm{~N} \mathrm{ha}^{-1}$ increased total production costs of 6 and $12 \%$, respectively, for both TDK8 and TDK11 (Table 6). N-fertilizer rates of 60 and $120 \mathrm{~kg} \mathrm{~N} \mathrm{ha}^{-1}$ contributed to yield increases of 50 and $87 \%$ for TDK 8 and 54 and $70 \%$ for TDK11, indicating that TDK8 responded to fertilizer application better than did TDK11. The net incomes for growing TDK8 with 0,60 and $120 \mathrm{~kg} \mathrm{~N}^{-1}$ were $147.5,563.0$ and 855.2 US $\$ \mathrm{ha}^{-1}$, respectively, while the net incomes for growing TDK11 were 201.9, 678.5 and 794.5 US $\$$ ha $^{-1}$, respectively. The relative net income for TDK8 went up by 382 and $580 \%$ when the rate of $\mathrm{N}$ application was increased from 0 to 60 and $120 \mathrm{~kg} \mathrm{~N} \mathrm{ha}^{-1}$, respectively, it went up by 336 and $393 \%$ for TDK11, respectively.

\section{Discussion}

\section{Model evaluation}

Differences in simulated data and observed data for days to harvest were in the range between +1 to -4 days and the major differences were TDK8 with $\mathrm{N}$-fertilizer at a rate of $80 \mathrm{~kg} \mathrm{~N} \mathrm{ha}^{-1}$ (-4 days) and TDK11 with $\mathrm{N}$-fertilizer at a rate of $73 \mathrm{~kg} \mathrm{~N}^{-1}$ (-3 days). The differences were partially due to inaccuracy in determining crop maturity which caused harvest delays by farmers.

The differences between observed and simulated yields were not particularly great. Most differences between simulated yield and observed yield were lower than $10 \%$ except for one crop cut which had a $16 \%$ difference. The simulated results are considered acceptable if the difference between simulated yield and actual yield is lower than $10 \%$ (Loague and Green, 1991). The disparities between the observed and simulated values were attributable to the fact that the crop in the actual farmers' fields had been affected by weeds, diseases and pests and other factors which were not taken into account by the model. In addition, error from fertility data could also result in differences between observation and simulation (Oteng-Darko et al., 2012; Yao et al., 2007).

The CSM-CERES-Rice model provided good simulated yields of glutinous lowland rice (Vilayvong et al., 2012). Overall, variations between observed and simulated yields are adequately accounted for and the CSM-CERES-Rice model could be used to determine the appropriate management practices for improving rice production in the Vientiane plain, Laos.

\section{Simulation for different management scenarios}

There was no difference in the yields of TDK8 and TDK11 although they were different in days to anthesis, days to harvest, biomass and harvest index. Difference in days to harvest is very useful for rice production. TDK11 may be better under terminal drought because it completes the life cycle earlier. Thus, it can alleviate the effect of terminal drought. In cases where soil preparation was delayed, TDK11 is also better than TDK8.

The increase in plant population density from 1 seedling hill ${ }^{-1}$ to 5 seedlings hill ${ }^{-1}$ slightly increased biomass and reduced harvest index, whereas grain yield seemed to be reduced for TDK11 cultivars. In previous investigations, 1 seedling hill ${ }^{-1}$ gave a higher net as- 


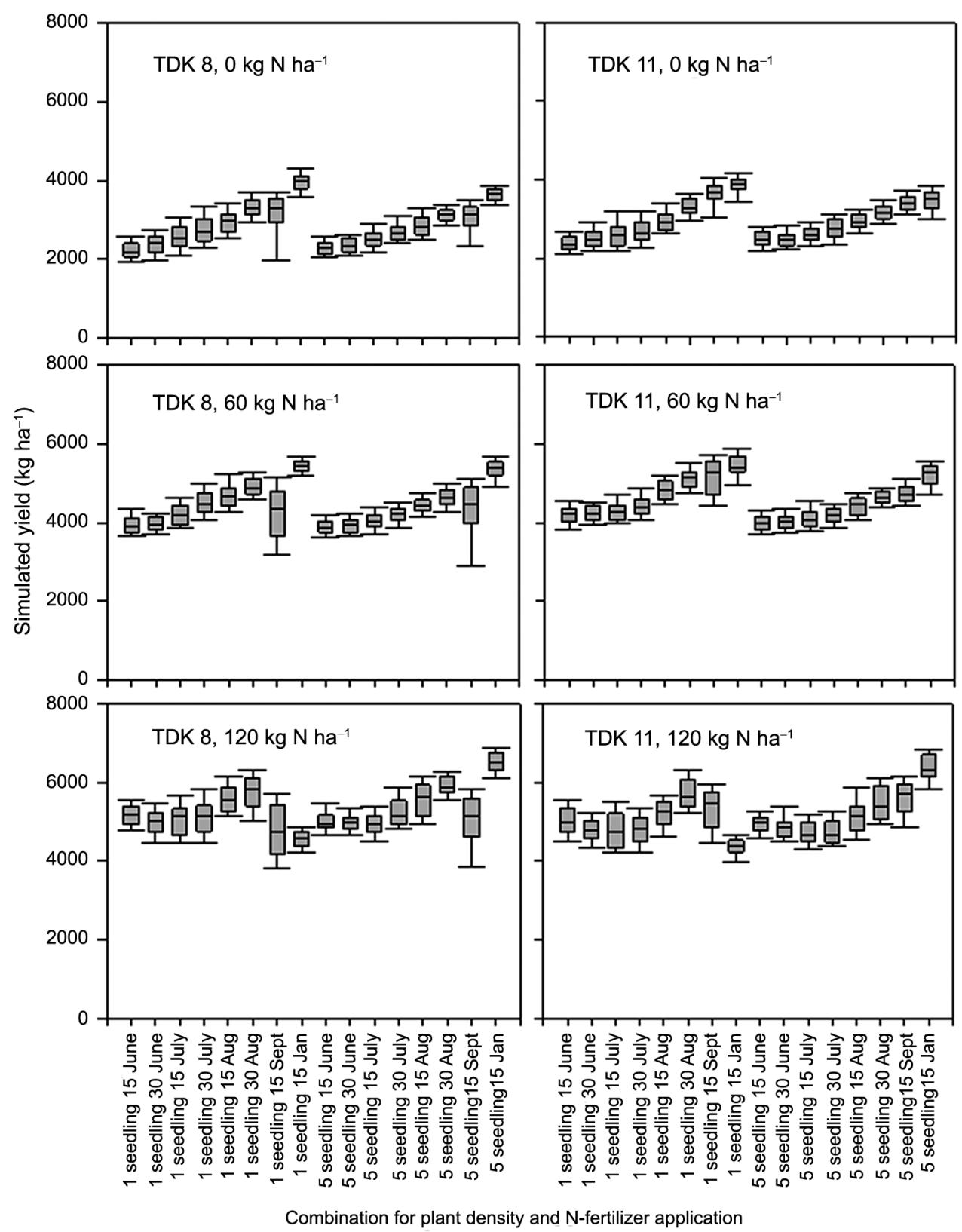

Figure 2 - Simulated grain yield for two rice cultivars, three rates of $\mathrm{N}$-fertilizer application, two rates of plant density and eight planting dates. The model was run for 33 years (from 1980 to 2012) for two soil types in the Vientiane plain, Laos. Box limits represent the $25^{\text {th }}$ and $75^{\text {th }}$ percentiles, box central line represents the median and outliers represent the minimum and maximum values.

similation rate which is the physiological potential for converting the total dry matter into grain yield (Baloch et al., 2006). Similarly, plant density of 1 seedling hill ${ }^{-1}$ of rice gave higher grain when compared to plant density of 2 seedlings hill ${ }^{-1}$ (Srinivasulu et al., 1999). In this study, a high assimilation rate did not contribute much to grain yield because the crop grown at 5 seedlings hill $^{-1}$ had higher biomass than the crop grown at 1 seeding hill ${ }^{-1}$. Grain yield in this study seems to be related to the harvest index instead of biomass. However, attaining high grain yield may be difficult in different contexts because grain yield is dependent on several factors such as soil moisture, soil fertility, agronomic practices, pests and diseases.

Increases in $\mathrm{N}$-fertilizer rates could increase both biomass and grain yield but they seemed to reduce harvest index. Greater increases in grain yield were found for $\mathrm{N}$-fertilizer at a rate of $60 \mathrm{~kg} \mathrm{~N} \mathrm{ha}^{-1}$ and grain yield 
Table 6 - Contribution of N-fertilizer application on total production cost, simulated grain yield for 2012 and income for TDK8 and TDK11 cultivars in Vientiane plain, Laos.

\begin{tabular}{|c|c|c|c|c|c|c|}
\hline \multirow{3}{*}{ Items } & \multicolumn{6}{|c|}{ Cultivar and $\mathrm{N}$-fertilizer rate $\left(\mathrm{kg} \mathrm{N} \mathrm{ha}^{-1}\right)$} \\
\hline & \multicolumn{3}{|c|}{ TDK8 } & \multicolumn{3}{|c|}{ TDK11 } \\
\hline & 0 & 60 & 120 & 0 & 60 & 120 \\
\hline Total production cost (US\$ ha $\left.{ }^{-1}\right)$ & 772.9 & 818.4 & 863.8 & 772.9 & 818.4 & 863.8 \\
\hline Relative total production cost (\%) & 100 & 106 & 112 & 100 & 106 & 112 \\
\hline Average simulated grain yield (kg ha-1) & 2,789 & 4,186 & 5,209 & 2,954 & 4,536 & 5,025 \\
\hline Relative grain yield (\%) & 100 & 150 & 187 & 100 & 154 & 170 \\
\hline Gross income (US\$ ha $\left.{ }^{-1}\right)^{a}$ & 920.4 & $1,381.4$ & $1,719.0$ & 974.8 & $1,496.9$ & $1,658.3$ \\
\hline Net income (US\$ ha-1) & 147.5 & 563.0 & 855.2 & 201.9 & 678.5 & 794.5 \\
\hline Relative net income (\%) & 100 & 382 & 580 & 100 & 336 & 393 \\
\hline
\end{tabular}

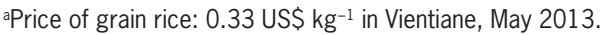

was increased albeit at a reducing rate when the crop was applied with $\mathrm{N}$-fertilizer at a rate of $120 \mathrm{~kg} \mathrm{~N}^{-1}$. Application of $\mathrm{N}$-fertilizer supports crop growth and final yield (Baloch et al., 2006). If the crop is not labile to natural disasters such as flooding, drought, insect pests and diseases, higher $\mathrm{N}$-fertilizer rate is highly recommended for attaining maximum yield and maximum profit.

Production of glutinous rice in this area depends heavily on $\mathrm{N}$-fertilizer input. In this study, application of $\mathrm{N}$-fertilizer at the rates of 60 and $120 \mathrm{~kg} \mathrm{~N} \mathrm{ha}^{-1}$ increased total production costs for both cultivars by 6 and $12 \%$, respectively. At these $\mathrm{N}$-fertilizer rates, changes in grain yield and net income were much higher than changes in production costs. In general, adding $\mathrm{N}$-fertilizer application under good management conditions farmers could obtain a satisfactory income from their rice growing.

The farmers in Laos usually transplant rice in-season (from June to Aug) depending on rainfall and rain distribution and they can also grow off-season rice in Jan with irrigation. In this study, we simulated in-season rice starting from 15 June to 15 Sept (seven transplanting dates) and off-season rice on 15 Jan to understand the effects of the transplanting date on growth and yield. For in-season rice, delayed transplanting from June to Sept caused slightly early anthesis in both TDK8 and TDK11. However, both cultivars seemed to have increased days to harvest with late transplanting dates. These results are similar to the observed values measured by Vilayvong et al. (2012) who maintained that TDK8 and TDK11 are non-photosensitive cultivars. Therefore, the variation in transplanting times would also have a key effect on life duration of these rice cultivars (Fukai, 1999).

Both TDK8 and TDK11 increased biomass with late transplanting dates of in-season rice but they reduced harvest index. Growing rice off-season with a transplanting date of 15 Jan gave high biomass, grain yield and harvest index when compared to in-season rice. This was caused by high solar radiation during the growing season. The average values of solar radiation for the entire growing season were 19.9, 16.7, 15.9, 15.4, $15.1,14.9,14.8$ and $14.8 \mathrm{MJ} \mathrm{m}^{-2}$ day $^{-1}$ for the transplanting dates of 15 Jan, 15 Sept, 30 Aug, 15 Aug, 30 July, 15 July, 30 June and 15 June, respectively.
A high solar radiation value for the entire growing season contributes to the high level of crop yield (Banterng et al., 2010). Solar radiation provides the energy for the processes that drive photosynthesis, affecting carbohydrate partitioning and biomass growth of the individual plant components (Hoogenboom, 2000). Considering the transplanting date, therefore, farmers are recommended to grow rice under both rainfed and irrigated conditions on 15 Jan, 30 July, 15 Aug, 30 Aug and 15 Sept to attain acceptable grain yield.

The highest simulated grain yield for the combination of rice transplanted on 15 Jan with 5 seedlings hill ${ }^{-1}$

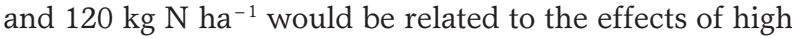
solar radiation during crop life duration, high $\mathrm{N}$-fertilizer input as well as suitable plant density. However, low values of simulated grain yields for the transplanting date of 15 Jan with 1 seedling hill-1 and $120 \mathrm{~kg} \mathrm{~N}^{-1}$ here also recorded and this because of over $\mathrm{N}$-fertilizer application. The simulated output from the model indicated that stress or nutrient toxicity was the result of a high input of $\mathrm{N}$-fertilizer during the panicle initiation stage to the beginning of the grain filling stage for the crop transplanted on 15 Jan along with 1 seedling hill ${ }^{-1}$ and $120 \mathrm{~kg} \mathrm{~N} \mathrm{ha}^{-1}$ and it reduced the total number of panicles and ultimately grain yield. Under no N-fertilizer application, however, transplanting with 5 seedlings hill ${ }^{-1}$ may face nutrient deficiency stress during the panicle initiation phase.

We demonstrated how the CSM-CERES-rice model could potentially assist in the determination of crop management schemes for rice production in tropical regions such as Laos. The model could provide valuable information in the design of agricultural management practices that will increase rice production in the Vientiane plain. To be able to identify crop management practices for a specific region, however, we suggest that the results both from a few years of actual experiments and from longterm simulation should be used to help design the best recommendations.

\section{Conclusion}

CSM-CERES-Rice model is an alternative tool for determining management practices for lowland rice in 
the Vientiane plain, Laos. The model evaluation results showed strong agreement between observed and simulated data. TDK8 and TDK11 cultivars were similar for grain yield. The transplanting methods of 1 seedling hill ${ }^{-1}$ and 5 seedlings hill $^{-1}$ produced similar grain yield for TDK8. Application of $\mathrm{N}$-fertilizer at the rates of 60 and $120 \mathrm{~kg} \mathrm{~N} \mathrm{ha}^{-1}$ could increase grain yield and net income. The transplanting date of 15 Jan gave the highest grain yield for both TDK8 and TDK11 when compared with the other transplanting dates. The management combination of irrigated rice transplanted on 15 Jan with 5 seedlings hill $^{-1}$ and $\mathrm{N}$-fertilizer at $120 \mathrm{~kg} \mathrm{~N}^{-1}$ is recommended for improving lowland rice production in Laos.

\section{Acknowledgements}

This study was supported by the Thailand research fund through the CLMV-T DSS graduate degree program research initiative: $1^{\text {st }}$ phase grant number RDG52O0003-LV05 of Assoc. Prof. Dr. Attachai Jintrawet, Chiang Mai University, Thailand. Assistance in conducting the work was received from the plant breeding research center for sustainable agriculture, Khon Kaen University, Khon Kaen, Thailand. Acknowledgement is also extended to Khon Kaen University and the Faculty of Agriculture for providing financial support for manuscript preparation activities.

\section{References}

Ahmad, S.; Ahmad, A.; Tojo Soler, C.M.; Ali, H.; Zia-Ul-Haq, M.; Anothai, J.; Hussain, A.; Hoogenboom, G.; Hasanuzzaman, M. 2012. Application of the CSM-CERES-Rice model for evaluation of plant density and nitrogen management of fine transplanted rice for an irrigated semiarid environment. Precision Agriculture 13: 200-218.

Baloch, M.S.; Awan, I.U.; Hassan, G. 2006. Growth and yield of rice as affected by transplanting dates and seedlings per hill under high temperature of Dera Ismail Khan, Pakistan. Journal of Zhejiang University SCIENCE B 7: 572-579.

Banterng, P.; Hoogenboom, G.; Patanothai, A.; Singh, P.; Wani S.P.; Pathak, P.; Tongpoonpol, S.; Atichart, S.; Srihaban, P.; Buranaviriyakul, S.; Jintrawet, A.; Nguyen, T.C. 2010. Application of the cropping system model (CSM)-CROPGROSoybean for determining optimum management strategies for soybean in tropical environments. Journal of Agronomy and Crop Science 196: 231-242.

Cheyglinted, S.; Ranamukhaarachchi, S.L.; Singh, G. 2001. Assessment of the CERES-Rice model for rice production in the central plain of Thailand. Journal of Agricultural Science 137: 289-298.

Fukai, S. 1999. Phenology in rainfed lowland rice. Field Crops Research 64: 51-60.

Geng, S.; Hess C.E.; Auburn, J. 1990. Sustainable agricultural systems: concepts and definitions. Journal of Agronomy and Crop Science 165: 73-85.

Gomez, K.A.; Gomez, A.A. 1984. Statistical Procedures for Agricultural Research. 2ed. John Wiley, New York, NY, USA.
Hoogenboom, G. 2000. Contribution of agrometeorology to the simulation of crop production and its applications. Agricultural and Forest Meteorology 103: 137-157.

Iqbal, S.; Ahmad, A.; Hussain, A.; Ali, M.A.; Khaliq, T.; Wajid, S.A. 2008. Influence of transplanting date and nitrogen management on productivity of paddy cultivars under variable environment. International Journal of Agriculture and Biology 10: $288-292$

Jones, J.W.; Hoogenboom, G.; Porter, C.H.; Boote, K.J.; Batchelor, W.D.; Hunt, L.A.; Wilkens, P.W.; Singh, U.; Gijsman, A.J.; Ritchie, J.T. 2003. The DSSAT cropping system model. European Journal of Agronomy 18: 235-265.

Lamsal, A.; Amgain, L.P. 2010. Simulation of growth and yield of rice under varied agronomic management and changing climatic scenario by using DSSAT ver. 4.0 crop model in Chitwan, Nepal. Journal of Hill Agriculture 1: 114-123.

Linquist, B.; Sengxua, P. 2001. Nutrient Management in Rainfed Lowland Rice in the Lao PDR. International Rice Research Institute, Los Banos, Philippines.

Loague, K.; Green, R.E. 1991. Statistical and graphical methods for evaluating solute transport models: overview and application. Journal of Contaminant Hydrology 7: 51-73.

Oteng-Darko, P.; Kyei-Baffour, N.; Ofori, E. 2012. Simulating rice yields under climate change scenarios using the CERES-Rice model. African Crop Science Journal 20: 401-408.

Sarkar, R.; Kar, S. 2006. Evaluation of management strategies for sustainable rice-wheat cropping system, using DSSAT seasonal analysis. Journal of Agricultural Sciences 144: 421-434.

Schiller, J.M.; Ladsavong, H.; Doungsila, K. 2006. A history of rice in Laos. p. 9-28. In: Schiller, J.M.; Chanphengxay, M.B.; Linqiust, B.; Appa Rao, S., eds. Rice in Laos. International Rice Research Institute, Los Banos, Philippines.

Singh, H.; Singh, K.N.; Hasan, B. 2007. Evaluation of CERES-rice model (V. 4.0) under temperate conditions of Kashmir valley, India. Cereal Research Communications 35: 1723-1732.

Srinivasulu, K.; Veeraraghavaiah, R.; Madhavi, K. 1999. Growth performance of rice hybrids under different methods and densities of planting. Crop Research 18: 1-7.

Timsina, J.; Connor, D.J. 2001. Productivity and management of rice-wheat cropping systems: issues and challenges. Field Crops Research 69: 93-132.

Timsina, J.; Humphreys, E. 2006. Performance of CERES-rice and CERES-wheat models in rice-wheat systems: a review. Agricultural System 90: 5-31.

Vilayvong, S.; Banterng, P.; Patanothai, A.; Pannangpetch, K. 2012. Evaluation of CSM-CERES-Rice in simulating the response of lowland rice cultivars to nitrogen application. Australian Journal of Crop Science 6: 1534-1541.

Wallach, D.; Goffinet, B. 1987. Mean squared error of prediction in models for studying ecological and agronomics systems. Biometrics 43: 561-573.

Yao, F.; Xu, Y.; Feng, Q.; Lin, E.; Yan, X. 2005. Simulation and validation of CERES-rice model in main rice ecological zones in China. Acta Agronomica Sinica 31: 545-550.

Yao, F.; Xu, Y.; Lin, E.; Yokozawa, M.; Zhang, J. 2007. Assessing the impacts of climate change on rice yields in the main rice areas of China. Climatic Change 80: 395-409. 